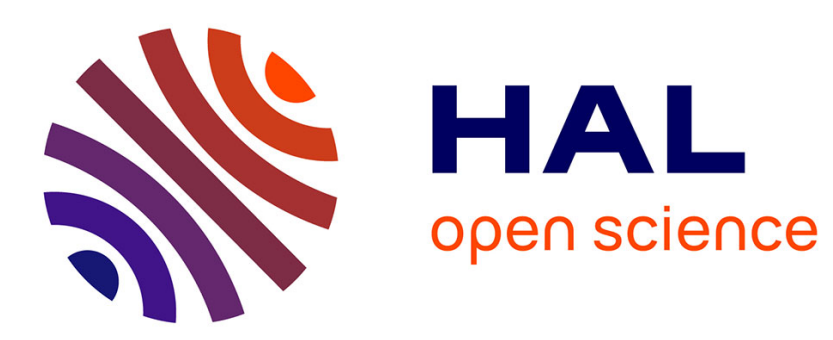

\title{
Thermal behaviour and excess entropy of bioactive glasses and Zn-doped glasses.
}

Eric Wers, Hassane Oudadesse

\section{To cite this version:}

Eric Wers, Hassane Oudadesse. Thermal behaviour and excess entropy of bioactive glasses and Zndoped glasses.. Journal of Thermal Analysis and Calorimetry, 2013, pp.1-8. 10.1007/s10973-0133280-3 . hal-00914284

\section{HAL Id: hal-00914284 \\ https://hal.science/hal-00914284}

Submitted on 5 Dec 2013

HAL is a multi-disciplinary open access archive for the deposit and dissemination of scientific research documents, whether they are published or not. The documents may come from teaching and research institutions in France or abroad, or from public or private research centers.
L'archive ouverte pluridisciplinaire HAL, est destinée au dépôt et à la diffusion de documents scientifiques de niveau recherche, publiés ou non, émanant des établissements d'enseignement et de recherche français ou étrangers, des laboratoires publics ou privés. 
J Therm Anal Calorim (2013) p: 1-8

DOI 10.1007/s10973-013-3280-3

Thermal behaviour and excess entropy of bioactive glasses and Zn-doped glasses

E. Wers, H. Oudadesse (

Received: 22 March 2013 / Accepted: 4 June 2013

E. Wers, H. Oudadesse ( D)

SCR, UMR CNRS 6226, University of Rennes 1, 263 av. du Général Leclerc, 35042 Rennes Cedex, France

Abstract Bioactive glasses prepared in $\mathrm{SiO}_{2}-\mathrm{CaO}-\mathrm{Na}_{2} \mathrm{O}$ and $\mathrm{P}_{2} \mathrm{O}_{5}$ system are used as biomaterials in orthopaedic and maxillofacial surgery. $\mathrm{Zn}$ presents high physiological interest. It enhances physiological effects of implanted biomaterials. In this work, the thermal characteristics $\left(T_{\mathrm{g}}, T_{\mathrm{c}}\right.$ and $\left.T_{\mathrm{f}}\right)$ of pure bioactive glass elaborated with different amounts of $\mathrm{CaO}, \mathrm{Na}_{2} \mathrm{O}$ in pure glass and with different amounts of introduced $\mathrm{Zn}$ in glass (ranging from 0.1 to $10 \mathrm{in} \mathrm{wt} \%$ ), were studied. The excess entropy was calculated for different compounds. Glasses were prepared by the melting process. The thermal behaviour of obtained bioactive glasses was determined using differential thermal analysis. Therefore, the glass transition $\left(T_{\mathrm{g}}\right)$, the crystallization $\left(T_{\mathrm{c}}\right)$ and the melting temperatures $\left(T_{\mathrm{f}}\right)$ were revealed. Moreover, according to Dietzel formula, the thermal stability (TS) of the studied bioactive glasses has been calculated. The first results concerning the impact of different oxides, revealed a decrease of the TS, $T_{\mathrm{g}}, T_{\mathrm{c}}$ and $T_{\mathrm{f}}$ when the $\mathrm{SiO}_{2} / \mathrm{CaO}$ increases and revealed an increase of these thermal characteristics when the $\mathrm{SiO}_{2} / \mathrm{Na}_{2} \mathrm{O}$ and $\mathrm{CaO} / \mathrm{Na}_{2} \mathrm{O}$ ratios increase. Introducing $\mathrm{Zn}$ into the bioactive glasses induces a decrease of $T_{\mathrm{f}}$ and an increase of TS. Contrary to crystals, prepared glasses have entropy different to zero at $T=0 \mathrm{~K}$ and vary versus $T_{\mathrm{f}}$. The excess entropy of pure glasses and $\mathrm{Zn}$-doped glasses were calculated. The significant variations were registered.

Keywords Bioactive glass, Zinc, Thermal characteristics, Entropy 


\section{Introduction}

Hench and al have discovered the first bioactive glass in the system $\mathrm{SiO}_{2}-\mathrm{CaO}-\mathrm{Na}_{2} \mathrm{O}-\mathrm{P}_{2} \mathrm{O}_{5}$ called Bioglass $^{\circledR}$. Since that discovery, different sorts of glasses, having wide range of chemical compositions, have been studied [1].

Bioactive glasses belong to ceramic family. Studied bioactive glasses are used as bone biomaterials in orthopaedic or maxillofacial surgery. The formation of a hydroxyapatite layer at the glass surface induces an intimate bone-bonding with the biomaterials [2-3].

Zinc is an element that presents a physiological interest in medicine and causes effects on the implanted biomaterials. Zinc is an important trace element in the human bones and improves the biomineralization both 'in vitro' and 'in vivo' experiments [4-7]. It takes part in the production of collagen [8], protein [9] and enzymatic processes [10].

The glass is an amorphous system with an unordered structure. It is not exposed to stoichiometric strain and can include variable chemical element within its matrix. The oxides used to synthesize glass are classified into three groups according to their functions. Network forming oxides can produce glass by themselves. Moreover, they are composed of metallic elements which can form multiple chemical bonds with the oxygen atoms. These oxides form polyhedrons that are tied by their peaks and give the vitreous network.

Network modifying oxides are the oxides composed of alkaline and alkaline-earth elements. Therefore, the introduction of alkaline elements forms discontinuities in the vitreous network and causes the decrease of the bioactive glass viscosity [11]. Moreover, alkaline oxides, for example $\mathrm{Na}_{2} \mathrm{O}$, sharply reduce the glass transition temperature of the bioactive glass [12]. Moreover, the introduction of an alkaline-earth element for example $\mathrm{CaO}$ has less impact on the glass transition temperature [12]. Furthermore, in a study of Cu-doped glasses, it is proved that the increasing of the content of $\mathrm{P}_{2} \mathrm{O}_{5}$ caused increase of solubility of copper in the structure of the glasses [13]. Intermediate elements include the modifiers and the formers elements according to the chemical composition of glasses. The principal intermediate elements in the glass oxides are: $\mathrm{Al}, \mathrm{Fe}, \mathrm{Ti}, \mathrm{Ni}$ and $\mathrm{Zn}$ [14] and were studied and used in metallic glasses for sky and sport equipment [15]. The introduction of certain metal elements involves specific modifications of the thermal behaviour. Indeed, molybdenum (Mo) introduced in glass matrix of silicate-phosphate glasses involves the decrease of the glass transition temperature, the heat specific and reduces the thermal stability (TS) [16]. However, if there are no enough alkaline ions, the zinc ion $\left(\mathrm{Zn}^{2+}\right)$ will be a network modifier by creating two oxygen bridges. Conversely, if there are enough alkaline ions, the zinc ion $\left(\mathrm{Zn}^{2+}\right)$ will be a network former [12]. 
Furthermore, it has been proved that the concentration of $\mathrm{ZnO}$ nanofillers significantly affects the thermal properties due to its catalytic behaviour in polymer matrix [17]. The addition of zinc ions to silicate and borosilicate glasses improves the thermal properties [14-18]. Studies have proved that a small content of $\mathrm{Zn}$ can improve the mechanical properties (fracture strength are higher) [19] and enhance the glass formal ability [19]. Furthermore, $\mathrm{Zn}$ is implicated in the lowering of melting point [19-20].

The purpose of this study is to investigate the effect of both different oxides and the introduction of $\mathrm{Zn}$ ions on the thermal characteristics of the bioactive glasses. Consequently, the entropy undergoes some variations between pure glasses and $\mathrm{Zn}$-doped glasses. For each chemical composition of glass, the excess entropy was calculated according to the variations of thermal characteristics of glasses. This entropy corresponds to the difference between the melting entropy of crystal and the entropy of glass. Contrary to crystals, prepared glasses have entropy different to zero at $T=0 \mathrm{~K}$ and vary versus $T_{\mathrm{f}}$ [21].

\section{Materials and methods}

\section{Preparation of bioactive glasses.}

Both undoped glasses and Zn-doped glasses had been synthesized from the composition of 46S6 (46 wt $\% \mathrm{SiO}_{2}, 24 \mathrm{wt} \% \mathrm{CaO}, 24 \mathrm{wt} \% \mathrm{Na}_{2} \mathrm{O}$ and $6 \mathrm{wt} \% \mathrm{P}_{2} \mathrm{O}_{5}$ ). Moreover, this bioactive glass composition 46S6 was studied by introduction of different concentrations of doped zinc ions from 0.1 to $10 \mathrm{wt} \%$ (46S6- $x \mathrm{Zn}$ where $x=0,0.1,1,5,8$ and 10). The low contents $(0.1$ and $1 \mathrm{wt} \%$ ) of zinc have been chosen because they correspond to the amount present in the bones. The other high contents $(5,8$ and $10 \mathrm{wt} \%$ ) were chosen to develop a porous biomaterials in a future work.

Chemical compositions of undoped glasses and doped glasses are summarized in Table $1\left(\mathrm{BG}_{\mathrm{i}=1-4}\right)$ and in Table 2 (46S6- $x \mathrm{Zn}$ ), respectively.

\begin{tabular}{|c|c|c|c|c|}
\hline & $\mathrm{CaO} / \mathrm{wt} \%$ & $\mathrm{Na}_{2} \mathrm{O} / \mathrm{wt} \%$ & $\mathrm{SiO}_{2} / \mathrm{wt} \%$ & $\mathrm{P}_{2} \mathrm{O}_{5} / \mathrm{wt} \%$ \\
\hline $\mathrm{BG} 1$ & 28 & 19.5 & 46.5 & 6 \\
\hline $\mathrm{BG} 2$ & 26 & 21 & 47 & 6 \\
\hline $\mathrm{BG} 3$ & 23 & 24.5 & 46.5 & 6 \\
\hline $\mathrm{BG} 4$ & 10 & 38.5 & 45.5 & 6 \\
\hline
\end{tabular}

Table 1 : Oxide compositions of bioactive glasses 


\begin{tabular}{|c|c|c|c|c|c|c|}
\hline & $\mathrm{SiO}_{2} / \mathrm{wt} \%$ & $\mathrm{CaO} / \mathrm{wt} \%$ & $\mathrm{Na}_{2} \mathrm{O} / \mathrm{wt} \%$ & $\mathrm{P}_{2} \mathrm{O}_{5} / \mathrm{wt} \%$ & $\mathrm{ZnO} / \mathrm{wt} \%$ & $\mathrm{Zn} / \%$ \\
\hline $46 \mathrm{~S} 6$ & 46 & 24 & 24 & 6 & 0 & 0 \\
\hline $\begin{array}{c}46 \mathrm{~S} 6- \\
0.1 \mathrm{Zn}\end{array}$ & 46 & 23.94 & 23.94 & 6 & 0.12 & 0.1 \\
\hline $46 \mathrm{S6} 6-1 \mathrm{Zn}$ & 46 & 23.38 & 23.38 & 6 & 1.24 & 1 \\
\hline $46 \mathrm{S6} 6-5 \mathrm{Zn}$ & 46 & 20.89 & 20.89 & 6 & 6.22 & 5 \\
\hline $\begin{array}{c}46 \mathrm{~S} 6- \\
8.1 \mathrm{Zn}\end{array}$ & 46 & 19 & 19 & 6 & 10 & 8.1 \\
\hline $46 \mathrm{~S} 6-10 \mathrm{Zn}$ & 46 & 17.78 & 17.78 & 6 & 12.44 & 10 \\
\hline
\end{tabular}

Table 2 : Oxide compositions of bioactive glasses doped with $\mathrm{Zn}$

For elaboration of the bioactive glass, sodium metasilicate $\left(\mathrm{Na}_{2} \mathrm{SiO}_{3}\right)$, silicon oxide $\left(\mathrm{SiO}_{2}\right)$, calcium metasilicate $\left(\mathrm{CaSiO}_{3}\right)$, sodium metaphosphate $\left(\mathrm{Na}_{3} \mathrm{P}_{3} \mathrm{O}_{9}\right)$ and zinc oxide $(\mathrm{ZnO})$ were weighed and mixed in a polyethylene bottle, for $2 \mathrm{~h}$ using a planetary mixer.

The premixed mixtures were melted in platinum crucibles that were placed in an electric furnace. The first rise of temperature rate was $10{ }^{\circ} \mathrm{C} \mathrm{min}^{-1}$ and it was hold at $900{ }^{\circ} \mathrm{C}$ for $1 \mathrm{~h}$ to achieve the decarbonation of all products. The second rise of temperature rate was $20{ }^{\circ} \mathrm{C} \mathrm{min}{ }^{-1}$ and it was hold to $1,350{ }^{\circ} \mathrm{C}$ for $3 \mathrm{~h}$. The thermal elaboration process was described in Fig. 1. The samples were casted in preheated brass molds, in order to form cylinders of $13 \mathrm{~mm}$ in diameter, and annealed at $565{ }^{\circ} \mathrm{C}$ for 4 $\mathrm{h}$ near the glass transition temperature of each glass. The obtained cylinders were used for the 'in vitro' evaluations test.

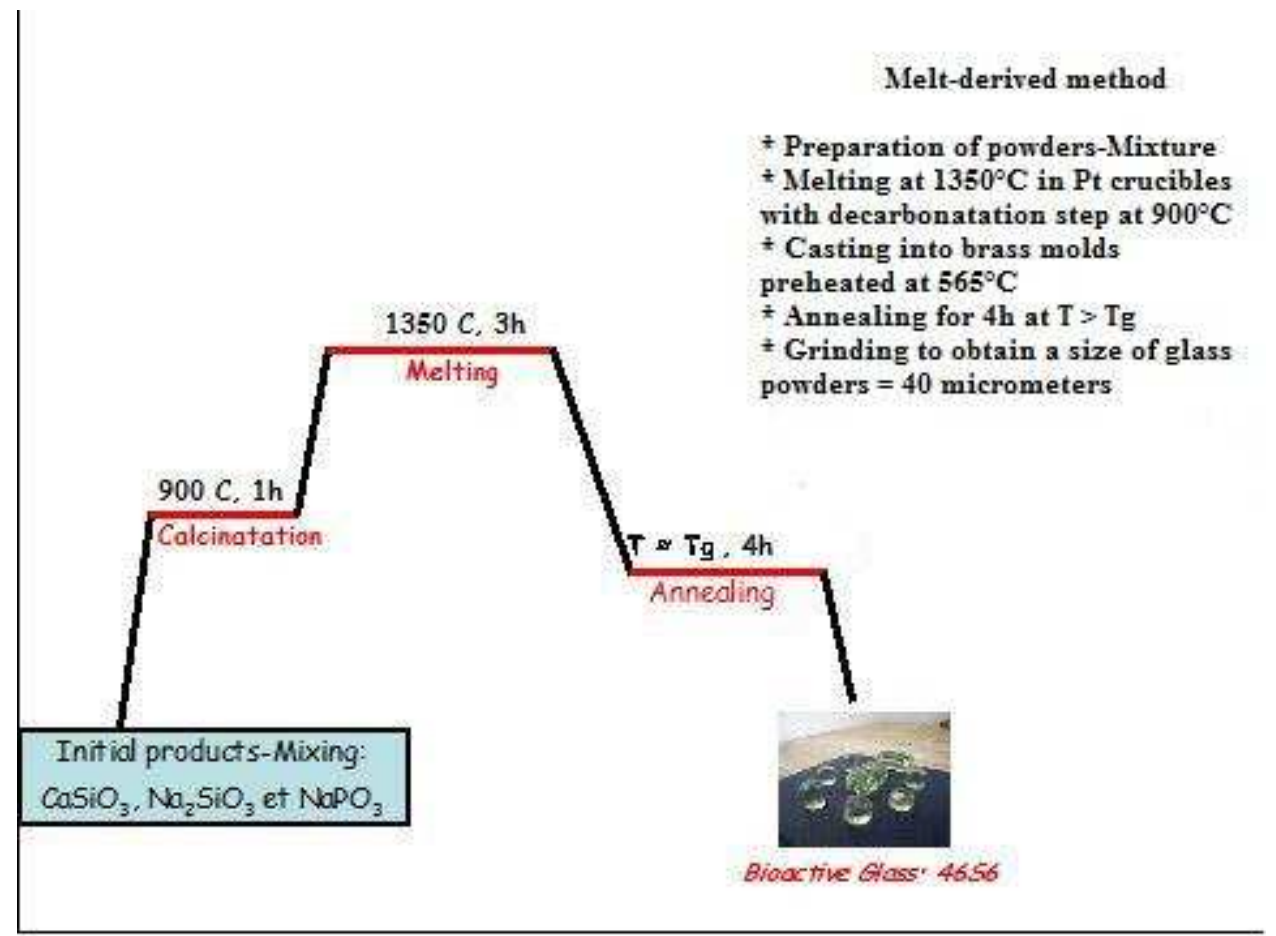

Fig 1 . The firing rate and the schedule of synthesis of glass 46S6 


\section{Thermal analysis}

Differential Thermal Analysis (DTA) was used to determine the characteristic temperatures of different bioactive glasses. The DTA principle is based on the detection of whether the phenomenon was exothermic or endothermic phenomenon. The glass transition temperature $T_{\mathrm{g}}$, the crystallization temperature $T_{\mathrm{c}}$ and the fusion temperature $T_{\mathrm{f}}$ have been recorded using a Setaram Labsys 1600TGDTA/DSC thermal analyzer under $\mathrm{N}_{2}$ gas atmosphere. Therefore, the onset temperature of crystallization $T_{\text {onset }} \mathrm{c}$ represented the beginning of the crystallization and the onset temperature fusion $T_{\text {onset }}$ f represented the beginning of the fusion have been recorded. The bioactive glasses were studied under heating rate of $5{ }^{\circ} \mathrm{C} \mathrm{min}^{-1}$ raised from room temperature to $1,400{ }^{\circ} \mathrm{C}$. Moreover, $40 \mathrm{mg}$ of the glass powder was heated in platinum crucible and, at the same time, another empty platinum crucible for use as control. The TS of bioactive glass has been expressed by the temperature difference between $T_{\mathrm{g}}$ and $T_{\text {onset }} \mathrm{c}$ introduced by Dietzel [22-24]:

$\mathrm{TS}=T_{\text {onset }} \mathrm{c}-T_{\mathrm{g}}$

Therefore, the high TS revealed the low tendency to crystallization [25].

\section{Results and discussion}

\section{Influence of oxides on the thermal characteristics of bioactive glasses}

Four bioactive glasses (BG1, BG2, BG3 and BG4), of different chemical compositions as shown in Table 1, have been studied. The $\mathrm{SiO}_{2} / \mathrm{CaO}, \mathrm{SiO}_{2} / \mathrm{Na}_{2} \mathrm{O}$ and $\mathrm{CaO} / \mathrm{Na}_{2} \mathrm{O}$ ratios of each $\mathrm{BG}_{\mathrm{i}=1-4}$ had been modified, in order to evaluate the effect of the oxides content on the thermal characteristic of the prepared bioactive glasses. The introduction of $\mathrm{Na}_{2} \mathrm{O}$ reduces the melting temperature and makes more soluble bioactive glasses after soaking in simulated body fluid. This phenomenon constitutes an important parameter for the bone-bonding implant-bone [26-29]. Moreover, $\mathrm{CaO}$ allows reducing the melt temperature without affecting the chemical durability of the glass. The simultaneous addition of $\mathrm{Na}_{2} \mathrm{O}$ and $\mathrm{CaO}$ induces an improvement of the chemical durability [30]. The increase of $\mathrm{CaO} / \mathrm{Na}_{2} \mathrm{O}$ ratio induces an increase of $T_{\mathrm{g}}$ from 434 to $550{ }^{\circ} \mathrm{C}, T_{\mathrm{c}}$ from 566 to $770{ }^{\circ} \mathrm{C}$ and $T_{\mathrm{f}}$ from 1,095 to 1,215 ${ }^{\circ} \mathrm{C}$ (Fig. 2a). An increase of the fusion temperature was observed when the content of $\mathrm{Na}_{2} \mathrm{O}$ decreases compared to the content of $\mathrm{CaO}$ and $\mathrm{SiO}_{2}$. Therefore, the introduction of the alkaline oxide $\mathrm{Na}_{2} \mathrm{O}$, in a small quantity, in comparison with the alkaline-earth oxide $\mathrm{CaO}$, has marked effect on both the glass transition and crystallization temperatures. 


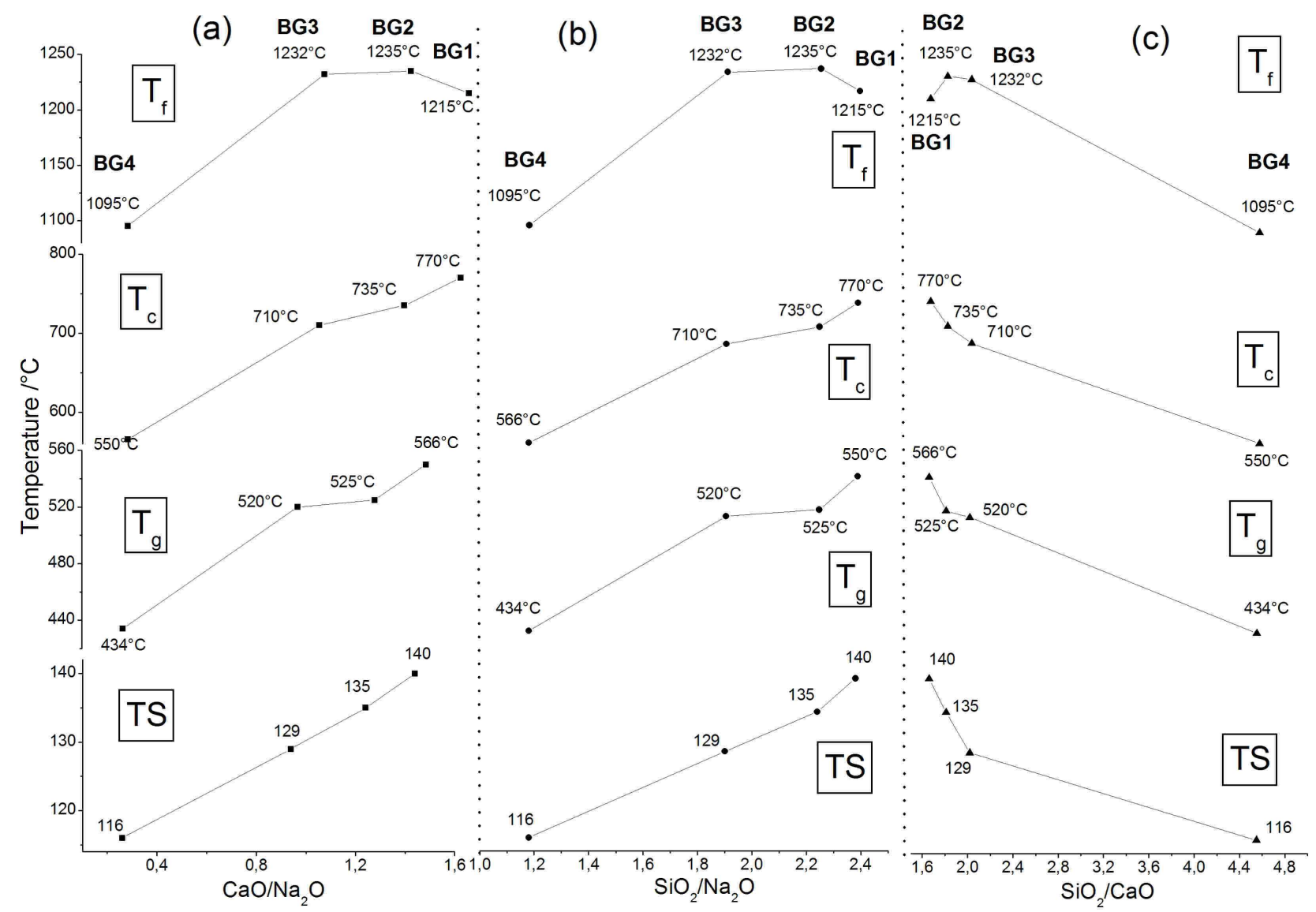

Fig 2 : a Characteristic temperatures functions of the $\mathrm{CaO} / \mathrm{Na}_{2} \mathrm{O}$ ratio. $\mathrm{b}$ Characteristic temperatures functions of the $\mathrm{SiO}_{2} / \mathrm{Na}_{2} \mathrm{O}$ ratio. c Characteristic temperatures functions of the $\mathrm{SiO}_{2} / \mathrm{CaO}$ ratio

The same changes were observed when the ratio $\mathrm{SiO}_{2} / \mathrm{Na}_{2} \mathrm{O}$ increases (Fig. 2b). However, the thermal behaviour was reversed when the $\mathrm{SiO}_{2} / \mathrm{CaO}$ ratio was raised (Fig. 2c).

Comparing the variation of these ratios, we can conclude that a high content of $\mathrm{Na}_{2} \mathrm{O}$ and a low content of $\mathrm{CaO}$ participate at the decrease of characteristic temperatures.

The introduction of $\mathrm{Na}_{2} \mathrm{O}$ creates two bridge-oxygens in the vitreous matrix. The two negative charges of oxygens are balanced by the charge of $\mathrm{Na}^{+}$pair forming a neutral electrostatic matrix. In this way, the network structure is modified and changes the glass properties like a decrease of the melting temperature.

The introduction of $\mathrm{CaO}$ does not change the network structure because the two positive charges of $\mathrm{Ca}^{2+}$ are balanced and create two tetrahedrons linked by ionic bonds. In this way, the glasses improve their chemical durability. The effect of zinc has been described. 


\section{Characterization of bioactive glasses doped with zinc}

The X-ray diffraction (XRD) patterns were recorded between 5 and $80(2 \theta)$, in 20 min, using a Bruker D8 advance diffractometer with $\mathrm{Cu} \mathrm{K} \alpha$ radiation. Obtained diffractograms of pure and Zn-doped glasses presented a halo of diffraction from 20 to $40(2 \theta)$ that was characteristic of an amorphous material. Amorphous character of bioactive glasses was not affected by the introduction of $\mathrm{Zn}$ with contents from 0.1 to $10 \mathrm{wt} \%$ (Fig. 3)

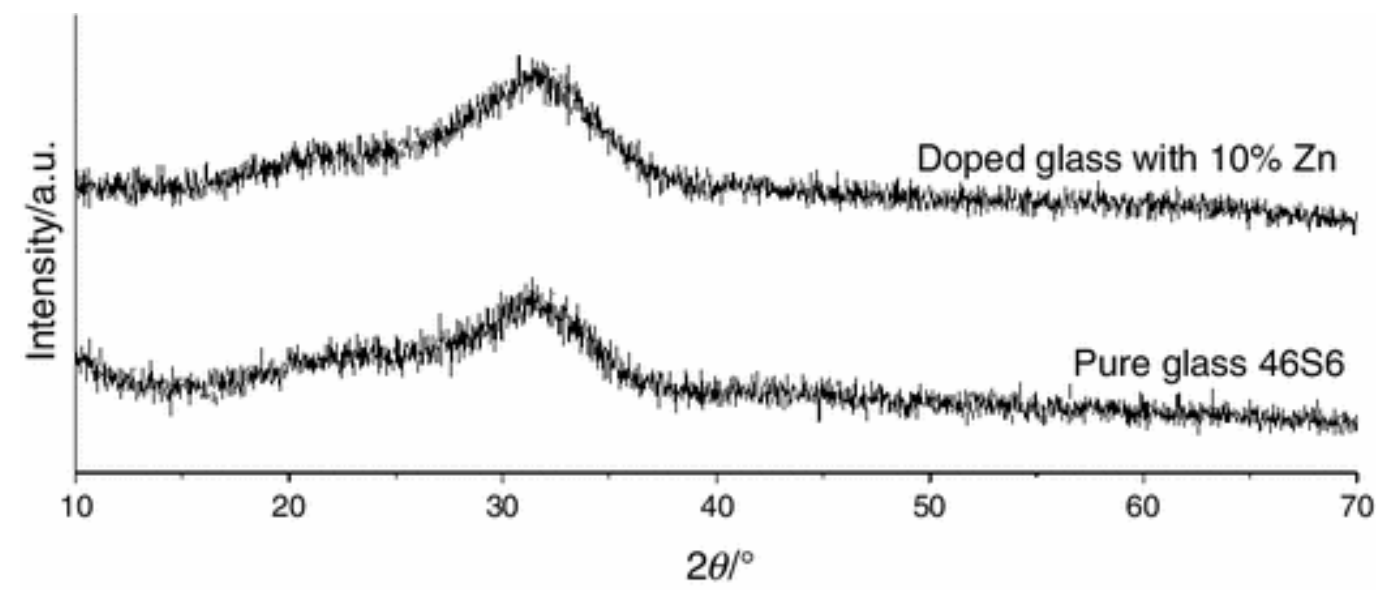

Fig3. X-ray diffractograms of pure glass and doped glass with $10 \% \mathrm{Zn}$

The infrared spectra were recorded by means of Fourier Transformed InfraRed (FTIR) spectrometer Bruker Equinox 55 between 4,000 and $400 \mathrm{~cm}^{-1}$ with a resolution of $2 \mathrm{~cm}^{-1}$. The infrared spectra of bioactive glasses revealed several characteristic bands (Fig. 4). Concerning all chemical compositions, the IR spectra confirmed the presence of Si-O-Si chemical bond at 1033, 924, 748 and $490 \mathrm{~cm}^{-1}$. The change at $600 \mathrm{~cm}^{-1}$ reveals the disappearance of the $\mathrm{P}-\mathrm{O}$ bend bond due to the addition of $5 \mathrm{wt} \%$ of zinc. Also, the appearance of band at $750 \mathrm{~cm}^{-1}$ (from $1 \mathrm{wt} \%$ of $\mathrm{Zn}$ ) corresponds to the formation of a new $\mathrm{Si}-\mathrm{O}-\mathrm{Si}$ chemical bond. 


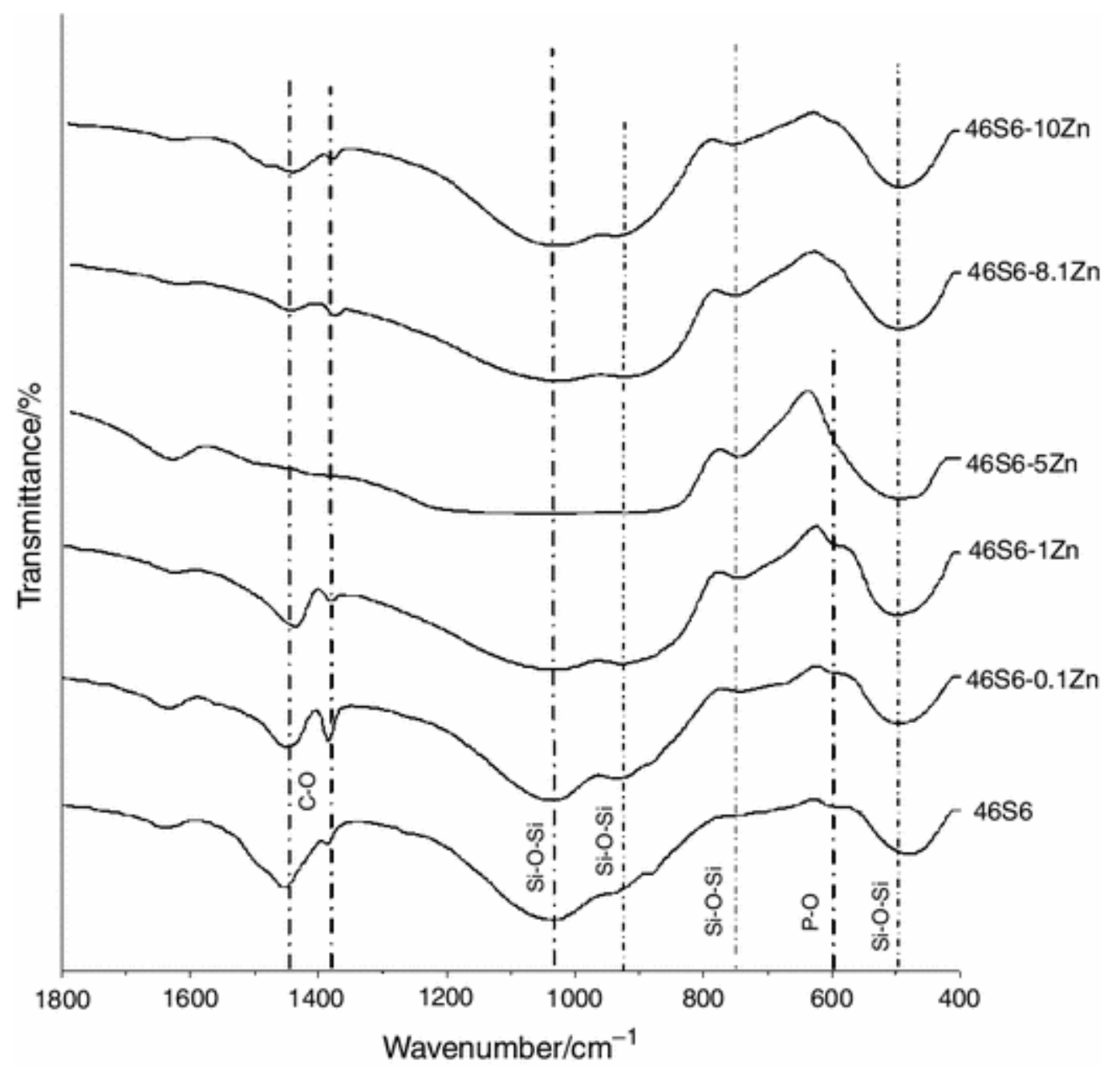

Fig 4. IR spectra of 46S6 and doped glasses 46S6-XZn $(0.1<\mathrm{X}<10)$

\section{Impact of the content of zinc on the thermal behaviour}

Concerning the bioactive glasses doped with zinc, the $\mathrm{CaO} / \mathrm{Na}_{2} \mathrm{O}$ ratio has been maintained equal to 1 $\left(\mathrm{CaO}=\mathrm{Na}_{2} \mathrm{O}=24 \mathrm{wt} \%\right)$. Amounts of alkaline oxide $\left(\mathrm{Na}_{2} \mathrm{O}\right)$ and alkaline-earth oxide $(\mathrm{CaO})$ decrease in favour of the quantity of zinc oxide introduced in glasses. DTA curves, at heating rate of $5{ }^{\circ} \mathrm{C} \mathrm{min}^{-1}$ are shown (Fig. 5) and the obtained thermal characteristics are summarized in Table 2. All the thermograms present 3 characteristic peaks, respectively, for the glass transition, crystallization and fusion temperatures. 


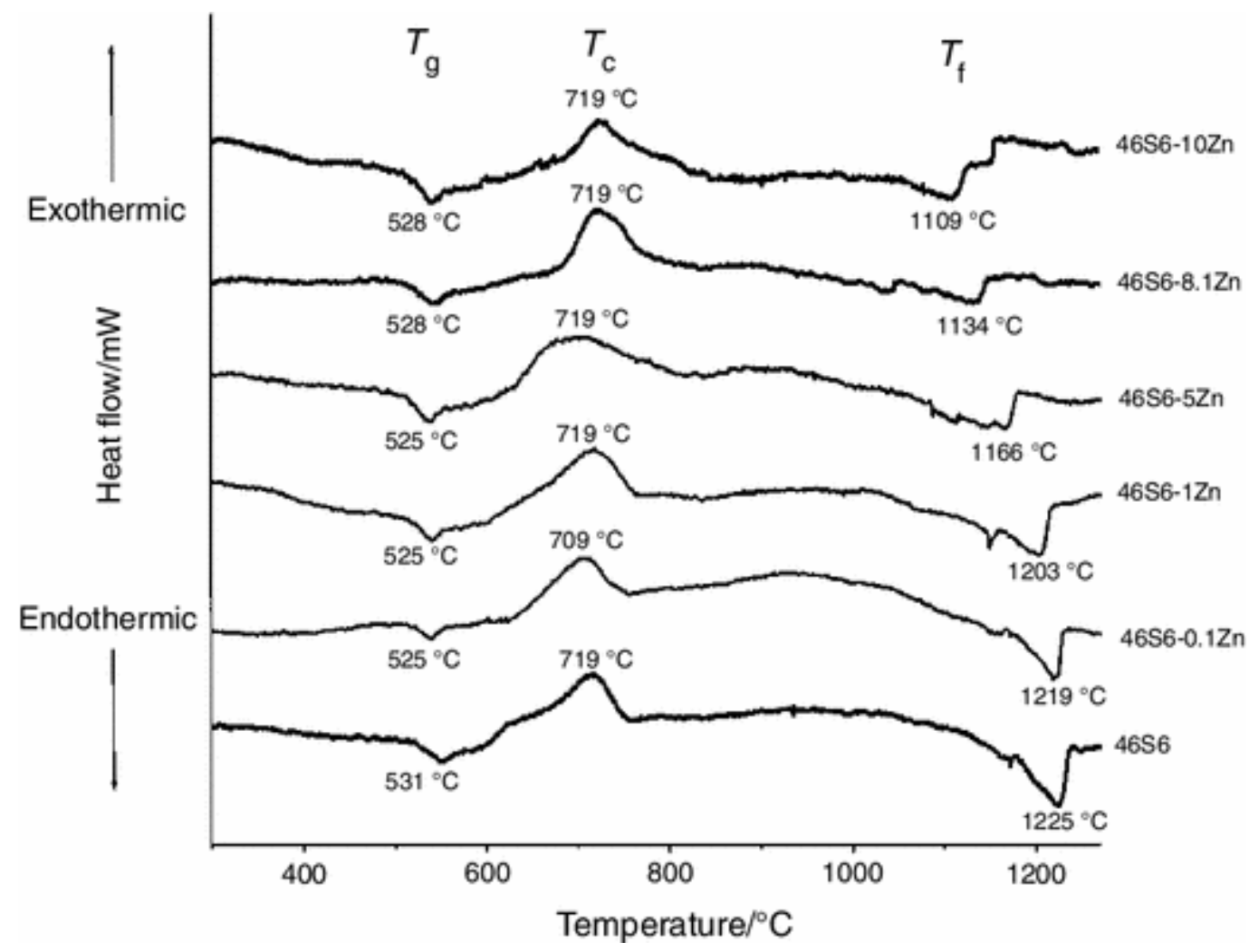

Fig 5. Thermal curves of 46S6 and doped glasses 46S6-XZn $(0.1<\mathrm{X}<10)$

Characteristic temperatures functions of the content of $\mathrm{ZnO}$ are presented in Fig. 6. It shows that the zinc content does not produce variations in the glass transition nor in the crystallization temperatures. Therefore, when the amount of zinc increases, the melting temperature decreases from 1,219 to 1,109 ${ }^{\circ} \mathrm{C}$. Consequently, TS increases widely from $103{ }^{\circ} \mathrm{C}$ when the content of $\mathrm{Zn}$ is between 0.1 and $5 \mathrm{wt} \%$ to $160{ }^{\circ} \mathrm{C}$ when the content of $\mathrm{Zn}$ is 8 and $10 \mathrm{wt} \%$ as shown in Fig. 6 . Mathematical relation between $T_{\mathrm{f}}$ and the content of zinc was elaborated.

$T_{\mathrm{f}}=1230-10.9 \tau_{\mathrm{Zn}}$ 


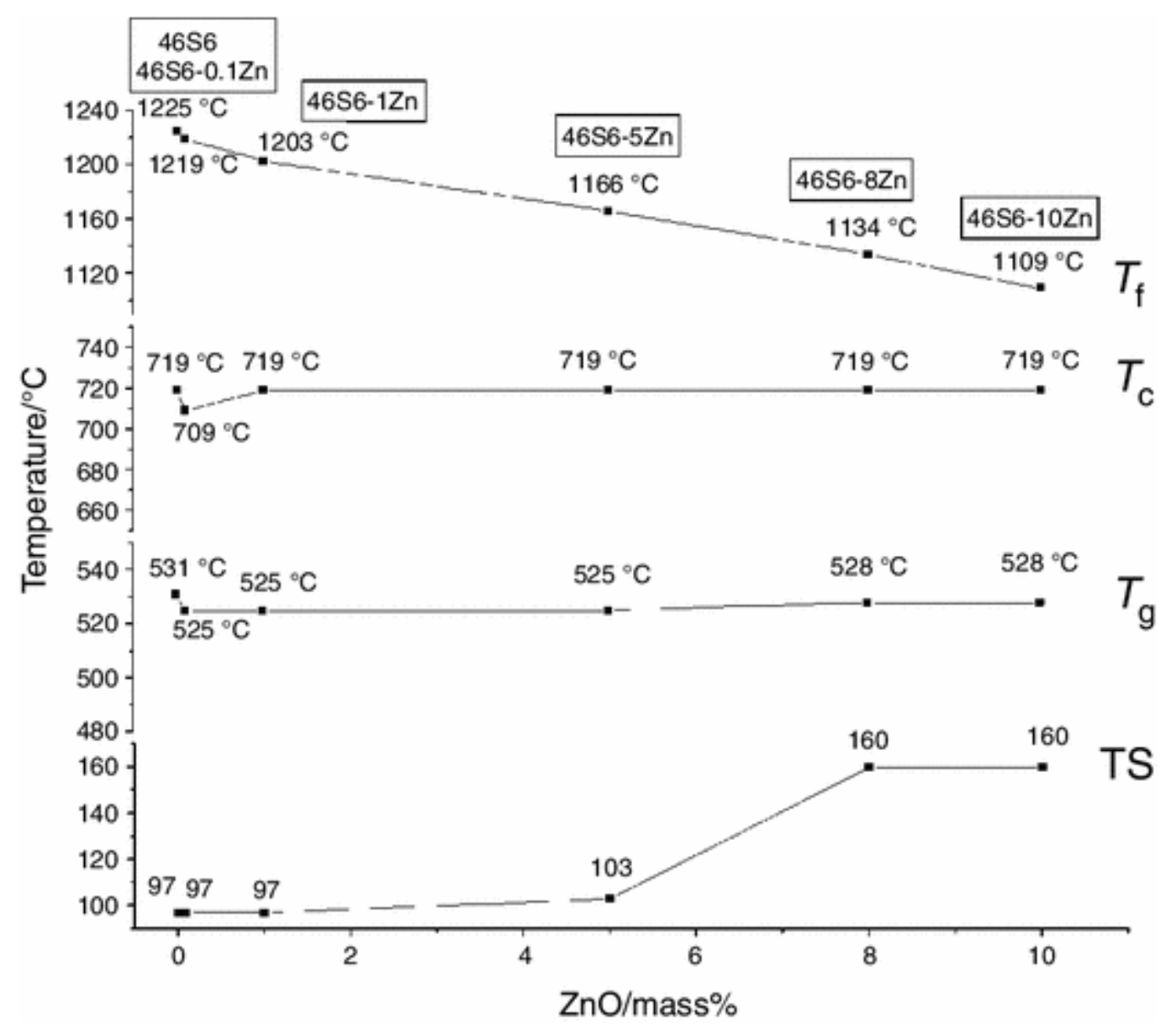

Fig 6. Characteristic temperatures functions of the content of $\mathrm{ZnO}$

$\tau_{\mathrm{Zn}}$ amounts of introduced $\mathrm{Zn}$ in glass.

The value of $1,230{ }^{\circ} \mathrm{C}$ represents the melting temperature of the undoped glass $46 \mathrm{~S} 6$.

Results are represented in Fig. 7. The amount of zinc increases the TS. More the concentration of $\mathrm{ZnO}$ is introduced into the glass, more the ratio between the amount of network modifying ions and amount of network modifying necessary to satisfy the environment of $\mathrm{Zn}^{2+}$ ions decreases. This could explain the decrease of the fusion temperature of the glasses. 


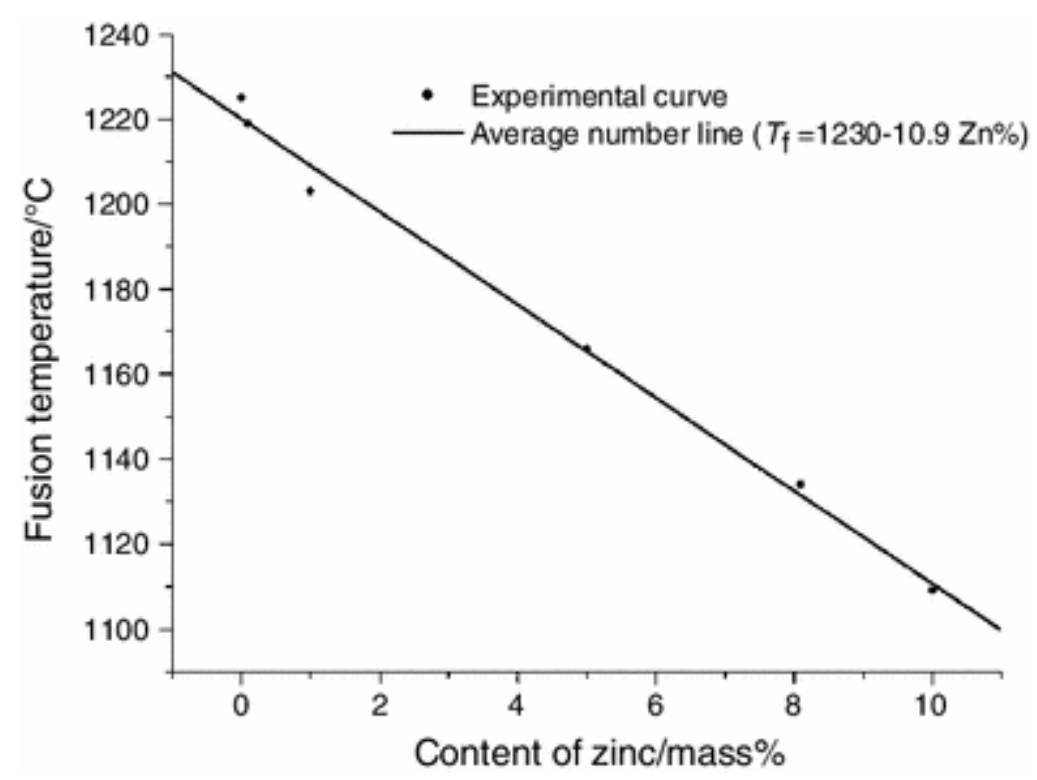

Fig 7. Characteristic temperatures functions of the content of $\mathrm{ZnO}$

We demonstrate through this practical study that the introduction of large amount of $\mathrm{Na}_{2} \mathrm{O}$ and small amount of $\mathrm{CaO}$ causes decrease of the glass transition and crystallization temperatures. In the glasses doped with zinc, the introduction of certain amount of $\mathrm{Na}_{2} \mathrm{O}$, equal to that of $\mathrm{CaO}$, do not produce variations in the glass transition nor in crystallization temperatures.

Being an intermediate oxide in the bioactive glasses, the increasing of the content of $\mathrm{ZnO}$ involves a decreasing of the melting temperature forming a linear relationship. The TS also increases when the content of zinc is important. $\mathrm{ZnO}$ is known to improve the hardness of silicate glasses.

The presence of a high $\mathrm{Zn}$ content decreases the melting temperature and increases the TS of the bioactive glass 46S6. These data can inform us about the viscosity of the glass, which is an important factor in the protocol of a porous biomaterial. We noticed that the higher the $\mathrm{Zn}$ content, the more the kinetic of bioactivity slowed down. Therefore, in the biomedical field, we could adapt the use of bioactive glasses according to age, gender and site of replacement.

\section{Excess entropy of glasses and Zn-doped glasses}

This attempt consists the calculation of the entropy at a temperature equal to $0 \mathrm{~K}$ for glasses and Zincdoped glasses in the quaternary system: $\mathrm{SiO}_{2}-\mathrm{CaO}-\mathrm{Na}_{2} \mathrm{O}-\mathrm{P}_{2} \mathrm{O}_{5}$.

The entropy of the liquid $S_{l}$ at a temperature $T>T_{\mathrm{f}}$ by the way crystal to liquid is [21]: 


$$
S_{\mathrm{l}}=S_{0}+\int_{0}^{T_{\mathrm{f}}} C p_{\mathrm{s}} \frac{\mathrm{d} T}{T}+\frac{\Delta H_{\mathrm{f}}}{T_{\mathrm{f}}}+\int_{T_{\mathrm{f}}}^{\mathrm{T}} C p_{\mathrm{l}} \frac{\mathrm{d} T}{T}
$$

when $C p_{\mathrm{s}}$ specific heat of crystalline solid, $C p_{1}$ specific heat of liquid, supercooled liquid or glass

$S_{0}$ corresponds to the entropy of the crystal at $\mathrm{T}=0 \mathrm{~K} . S_{0}=0$ according to the third principle of thermodynamic.

The same relation of $S_{1}$ is obtained by the way glass to liquid [21]. The corresponding equation is:

$$
S_{\mathrm{l}}=S_{0}^{\prime}+\int_{0}^{T_{\mathrm{g}}} C p_{\mathrm{l}} \frac{\mathrm{d} T}{T}+\int_{T_{\mathrm{g}}}^{T_{\mathrm{f}}} C p_{\mathrm{l}} \frac{\mathrm{d} T}{T}+\int_{T_{\mathrm{f}}}^{T} C p_{\mathrm{l}} \frac{\mathrm{d} T}{T}
$$

The identification of the two equations conducts to the establishment of the entropy $S_{0}^{\prime}$ of glass at $T=$

$0 \mathrm{~K}$. This relation is:

$$
S_{0}^{\prime}=\frac{\Delta H_{\mathrm{f}}}{T_{\mathrm{f}}}-\int_{0}^{T_{\mathrm{f}}}\left(C p_{\mathrm{l}}-C p_{\mathrm{s}}\right) \frac{\mathrm{d} T}{T}
$$

The variation of the entropy can be deducted by the following relation:

$\Delta S=S($ liquid or glass $)-S($ crystal $)$

At a temperature $T<T_{\mathrm{f}}$ :

$$
\begin{aligned}
& \Delta S=\frac{\Delta H_{\mathrm{f}}}{T_{\mathrm{f}}}-\int_{T_{\mathrm{g}}}^{T_{\mathrm{f}}}\left(C p_{1}-C p_{\mathrm{s}}\right) \frac{\mathrm{d} T}{T} \\
& \Delta S=\frac{\Delta H_{f}}{T_{f}}-2.09 \operatorname{Ln} \frac{T_{f}}{T_{g}}+0.48 \times 10^{-3}\left[T_{f}-T_{g}\right]
\end{aligned}
$$


Obtained results show that values obtained for bioactive glasses 46S6 (BG1, BG2, BG3 and BG4) and $\mathrm{Zn}$-doped glasses are not equal to zero. However, the excess entropy is of 72.8-78.3 $\mathrm{J} \mathrm{K}^{-1}$ for pure glass as shown in Table 3 when the presence of $\mathrm{Zn}$ reduces this excess entropy which varies from 78.3 to $39.8 \mathrm{~J} \mathrm{~K}^{-1}$ depending on amount of zinc in the glass matrix as shown in Table 4 and in Fig. 8. Our results are in agreement with the Zarzycki theory. We conclude that the third principle of thermodynamic is not applicable to bioactive glasses elaborated in the quaternary system $\mathrm{SiO}_{2}-\mathrm{CaO}-$ $\mathrm{Na}_{2} \mathrm{O}-\mathrm{P}_{2} \mathrm{O}_{5}$. This result will contribute on the comprehension of the changes of the kinetic of bioactivity of $\mathrm{Zn}$-doped bioactive glass compared to pure glass [31].

\begin{tabular}{|l|l|l|l|l|}
\hline & BG3 & BG2 & BG1 & BG4 \\
\hline$L_{\mathrm{f}} / \mathrm{J} \cdot \mathrm{kg}^{-1}$ & 118 & 117 & 113 & 101 \\
\hline$T_{\mathrm{g}} / \mathrm{K}$ & 793 & 798 & 828 & 707 \\
\hline$T_{\mathrm{f}} / \mathrm{K}$ & 1505 & 1508 & 1488 & 1368 \\
\hline$\Delta S / \mathrm{J} \cdot \mathrm{K}^{-1}$ & 78.03 & 76.59 & 75.03 & 72.76 \\
\hline
\end{tabular}

Table 3. Excess entropy of pure glasses

\begin{tabular}{|l|c|c|c|c|c|c|}
\hline & $46 \mathrm{S6}$ & $46 \mathrm{~S} 6-0.1 \mathrm{Zn}$ & $46 \mathrm{S6}-1 \mathrm{Zn}$ & $46 \mathrm{S6}-5 \mathrm{Zn}$ & $46 \mathrm{S6}-8 \mathrm{Zn}$ & $46 \mathrm{S6}-10 \mathrm{Zn}$ \\
\hline$L_{\mathrm{f}} / \mathrm{J} \cdot \mathrm{kg}^{-1}$ & 120.24 & 118.3 & 77.8 & 61.8 & 57.9 & 56.2 \\
\hline$T_{\mathrm{g}} / \mathrm{K}$ & 804 & 798 & 798 & 798 & 801 & 801 \\
\hline$T_{\mathrm{f}} / \mathrm{K}$ & 1498 & 1492 & 1476 & 1439 & 1407 & 1382 \\
\hline$\Delta S / \mathrm{J} . \mathrm{K}^{-1}$ & 79.27 & 78.31 & 51.75 & 42.02 & 40.3 & 39.80 \\
\hline
\end{tabular}

Table 4. Excess entropy of glasses doped with different amounts of Zinc (0-10 mass\%)

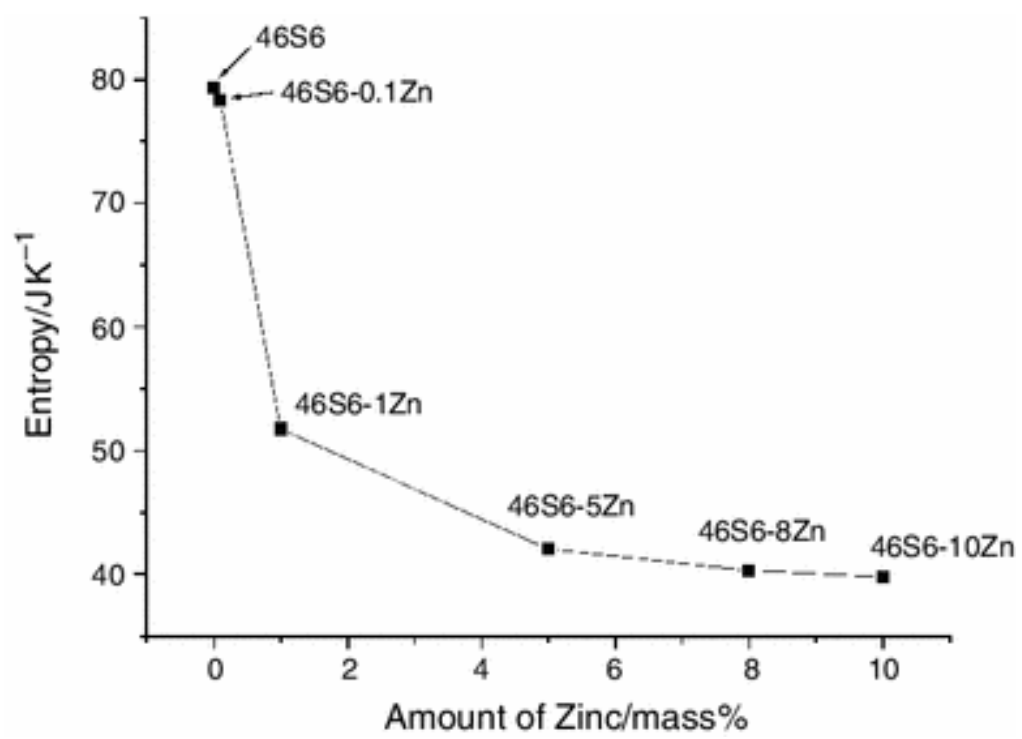

Fig 8. Excess entropy of pure glass and $\mathrm{Zn}$-doped glasses 


\section{Conclusions}

The characterization of bioactive glasses emphasizes the amorphous character of bioactive glasses and their predominant chemical bonds.

However, the introduction of the alkaline oxide $\mathrm{Na}_{2} \mathrm{O}$, induces a decrease of both glass transition and crystallization temperatures, the introduction of $\mathrm{CaO}$ induces their increase.

Moreover, the introduction of zinc in the glass matrix causes modifications in the thermal characteristics of the bioactive glasses. The glass transition and the crystallization temperatures do not present modifications. The presence of zinc has an important impact on the melting temperature and the TS of the studied bioactive glasses. Therefore, more the zinc content increases into the glass matrix, the more the melting temperature decreases and the TS increases.

The excess entropy of pure glass is important relatively to $\mathrm{Zn}$-doped glass. The presence of $\mathrm{Zn}$ reduces the excess entropy from 78.3 to only $39.8 \mathrm{~J} \mathrm{~K}^{-1}$ depending on the amount of zinc in the glass matrix.

The understanding of the thermal behaviour has allowed us to develop a protocol for the synthesis of porous biomaterial. Furthermore, changes in the thermal behaviour of glasses have an impact on their chemical reactivity. Depending to the content of the doping element, glass degrades more or less once in contact with a simulated body fluid and the kinetic of bioactivity can be changed. This provides to adapt the use of the bioactive glasses according to age, sex, morphology, site of implantation of the patient. 


\section{References}

[1] Hench LL, Splinter RJ, Allen WC, Greenlee Jr TK. Bonding mechanism at the interface of ceramics prosthetic materials. J Biomed Mater Res Symp 2. 1971; 5: 117-41

[2] Kokubo T, Kushitani H, Ohtsuki C, Sakka S, Yamamuro T. Effects of ions dissolved from bioactive glass-ceramic on surface apatite formation. J Mater Sci Mater Med. 1993; 4: 1-4

[3] Vallet-Reg1 M, Izquierdo-Barba I, Salinas AJ. Influence of $\mathrm{P}_{2} \mathrm{O}_{5}$ on crystallinity of apatite formed in vitro on surface of bioactive glasses. J Biomed Mater Res. 1999; 46: 560-5

[4] Storrie H, Stupp SI. Cellular response to zinc-containing organoapatite: an in vitro study of proliferation, alkaline phosphatase activity and biomineralization. Biomaterials. 2005; 26: 5492-9

[5] Yamaguchi M, Oishi H, Suketa Y. Stimulatory effect of zinc on bone formation in tissue culture. Biochem Pharmacol. 1987; 36: 4007-12

[6] Eberle J, Schmidmayer S, Erben RG, Stangassinger M, Roth HP. Skeletal effects of zinc deficiency in growing rats. J Trace Elem Med Bio. 1999; 13: 21-6

[7] Chen D, Waite LC, Pierce JWM. In vitro effects of zinc on markers of bone formation. Biol Trace Elem Res 1999; 68: 225-34

[8] Wu X, Itoh N, Taniguchi T, Nakanishi T, Tatsu Y, Yumoto N,Tanaka K. Zinc-induced sodiumdependent vitamin $\mathrm{c}$ transporter 2 expression: potent roles for osteoblast differentiation. Arch Biochem Biophys 2003; 420: 114-20

[9] Sauer GR, Wuthier RE. Influence of trace metal ions on matrix vesicle calcification. Bone Miner 1992; 17: 284-9

[10] Sauer GR, Wu LNY, Iijima M, Wuthier RE. The influence of trace elements on calcium phosphate formation by matrix vesicles. J Inorg Biochem. 1997; 65: 57-65

[11] Scholze H. Glas, Natur, Struktur und Eigenschaften,. Berlin: Springer; 1977

[12] Barton J, Guillemet C. Le verre: science et technologie. Les Ulis: EDP Sciences; 2004

[13] Sułowska J, Wacławska I, Szumera M. Effect of copper addition on glass transition of silicatephosphate glasses. J Therm Anal Calorim. 2012; 109: 705-10 
[14] Martinez V. Influence des effets thermiques et mécaniques sur la relaxation structurale des préformes et des fibres optiques à base de silice. Etude par diffusion de la lumière et par diffusion des rayons X. Thèse Université Lyon 1, numéro d'ordre 181; 2004

[15] Patel AT, Pratap A. Study of kinetics of glass transition of metallic glasses. J Therm Anal Calorim. 2012; 110: 567-71

[16] Szumera M, Waclawska I. Effect of molybdenum addition on the thermal properties of silicatephosphate glasses. J Therm Anal Calorim. 2012; 109: 649-55.

[17] Gaur MS, Singh PK, Suruchi, Chauhan RS. Structural and thermal properties of polysulfone-ZnO nanocomposites. J Therm Anal Calorim. 2013; 111: 743-51.

[18] Linati L, Lusvardi G, Malavasi G, Menabue L, Menziani MC, Mustarelli P. Qualitative and quantitative structure-property relationships analysis of multicomponent potential bioglasses. J Phys Chem B 2005; 109: 4989-98

[19] Gao P, Xue Z, Liu G, Zhang J, Zhang M. Effects of Zn on the glass forming ability and mechanical properties of MgLi-based bulk metallic glasses. J Non-Cryst Solids 2012; 358: 8-13

[20] Karbasi M, Saidi S, Aryanpour G. Study of structure and usage of mechanically alloyed nanocrystalline Ti-Cu-Zn powders in powder metallurgy. Powder Metall. 2008; 51: 250-3

[21] Zarzycki J. Les verres et l'état vitreux. Paris: Masson; 1982

[22] Pascuta P, Bosca M, Borodi G, Culea E. Thermal structural and magnetic properties of some zinc phosphate glasses doped with manganese ions. J Alloys Compd. 2011; 509: 4314-9

[23] Dietzel A. Glasstruktur und Glaseigenschaften. Glass Technol. 1968; 22: 41

[24] Kumar V, Sharma S, Pandey OP, Singh K. Thermal and physical properties of $30 \mathrm{SrO}-40 \mathrm{SiO}_{2}-$ $20 \mathrm{~B}_{2} \mathrm{O}_{3}-10 \mathrm{~A}_{2} \mathrm{O}_{3}(\mathrm{~A}=\mathrm{La}, \mathrm{Y}, \mathrm{Al})$ glasses and their chemical reaction with bismuth vanadate for SOFC. Solid State Ionics. 2010; 181: 7

[25] Bardez I. Etude des caractéristiques structurales et des propriétés de verres riches en terres rares destinés au confinement des produits de fission et éléments à vie longue. Thèse de l'Université Pierre et Marie, Curie Paris IV. 
[26] Siqueira RL, Peitl O, Zanotto ED. Gel-derived $\mathrm{SiO}_{2}-\mathrm{CaO}-\mathrm{Na}_{2} \mathrm{O}-\mathrm{P}_{2} \mathrm{O}_{5}$ bioactive powders: synthesis and in vitro bioactivity. Mater Sci Eng. 2011; 31: 983-91

[27] Hench LL. The story of Bioglass ${ }^{\circledR}$. J Mater Sci Mater Med. 2006; 17: 967-78

[28] Hench LL. Genetic design of bioactive glass. J Eur Ceram Soc. 2009; 29: 1257-65

[29] Jones JR, Gentleman E, Polak J. Bioactive glass scaffolds for bone regeneration. Elements. 2007; 3: 393-9

[30] Angeli F, Boscarino D, Gin S, Mea GD, Boizot B, Petit JC. Influence of calcium on sodium aluminosilicate glass leaching behaviour. Phys Chem Glasses. 2001; 42: 279

[31] Dietrich E, Oudadesse H, Lucas-Girot A, LeGal Y, Jeanne S, Cathelineau G. Effects of Mg and $\mathrm{Zn}$ on the surface of doped melt-derived glass for biomaterials applications. Appl Surf Sci. 2008; 255: $391-5$ 


\section{Caption figures:}

Fig. 1 The firing rate and the schedule of synthesis of glass 46S6

Fig. 2 a Characteristic temperatures functions of the $\mathrm{CaO} / \mathrm{Na}_{2} \mathrm{O}$ ratio. b Characteristic temperatures functions of the $\mathrm{SiO}_{2} / \mathrm{Na}_{2} \mathrm{O}$ ratio. c Characteristic temperatures functions of the $\mathrm{SiO}_{2} / \mathrm{CaO}$ ratio

Fig. $3 \mathrm{X}$-ray diffractograms of pure glass and doped glass with $10 \% \mathrm{Zn}$.

Fig. 4 IR spectra of 46S6 and doped glasses 46S6-XZn $(0.1<X<10)$

Fig. 5 Thermal curves of 46S6 and doped glasses 46S6-XZn $(0.1<X<10)$

Fig. 6 Characteristic temperatures functions of the content of $\mathrm{ZnO}$

Fig. 7 Variation of the fusion temperature functions of the content of zinc

Fig. 8 Excess entropy of pure glass and Zn-doped glasses. 